\begin{tabular}{l}
\hline 討 \\
\hline
\end{tabular}

三浦一郎・杉木六郎：フライアッシュを混和したモルタル 中の鉄筋のさび

(シンポジウムの席上におけるもの)

討 議 者:国 分 正 胤*

フライアッシュがコンクリート中に埋込まれた鉄筋の窗蝕におよばす影響は, 重要な研究題目でありますが, 土木方面ではあまり研究されておりません。三浦・杉木両氏の研究が最初の発表ではないかと思います。先鞭を つけられた両氏に敬意を表します。

ての研究に土木方面が無関心であった理由は，所要の品質をもつウォーカブルなコンクリートを入念に打込み 締固め十分に養生する場合には，フライアッシュの有無にかかわらず，コンクリート中の鉄筋が錆びるおそれは ほとんどないと信じていることによるのであります。しかし，御承知のようにフライアッシュの JIS**には，そ の末尾に“鉄筋コンクリートの建築物は，一般にかぶりが少なく，コンクリートの養生条件も十分でない場合が あるから，その地上部分にフライアッシュを用いるときは，かふりのの厚さの増加，調合の改善などに注意するこ と”の付記があります。との付記に関しては工業技術院のフライアッシュ專門委員会で長期にわたり論議が交さ れたのでありまして, 委員長の吉田徳次郎先生も最初は, “使用上の注意を規格に付記することは, 砂糖の規格 に“食べ過ぎると胃病になるから注意するてどと付記するよう\%もので不合理である”と反対されておられま した。しかし，最後にてれを認められたいきさつは次のとおりで西ります。

付記㤬東大教授の浜田 稔委員の提案によるものですが，同 委員の主張は, “ニンクリートが外気に曝されていると, 空気 中の炭酸ガスが除々にコンクリート中の水酸化石灰に吸収され， 従ってアルカリ性であったコンクリートは表面から内部に向っ て次第に中性化してゆく。フライアッシュを添加すると炭酸ガ スによる中性化が促進される。中性化すればニンクリート沉埋 込まれた鉄筋注錆び始める。鉄筋が錆び始めても, 直らに建築 物が崩壤するのではなく, 発銷が進行してかぶりコンクリート が涂落し，居住湛光なくなるまでには，なお幾年かを要する ことは当然である。しかし，この間に大きな地震でもあ机ば非 常に危険となる。建築部材の構造計算飞和ける鉄筋の短期許容 沁力度は $2400 \mathrm{~kg} / \mathrm{cm}^{2}$ であるが，建築物化最も多く用いられ る丸銅 SS 39 の降伏点はこの值と大差ない。従って鉄筋が発 錆して断面が減少すれば，設計計算で考慮した地震力には堪㫕

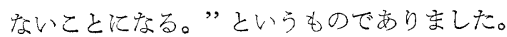

この論旨に対して九大名誉教授の張 玄彦委員は, “(i) フ ライアッシュを加えてコンクリートを造ると，七メントの水和 によって遊離した水酸化石灰と, フライアッシュ中の可溶性珪 酸技よび禁土とが化合するから，コンクリートの中性化が促進 されることは当然である。しかし，コンクリートが中性化した らただちに鉄筋が錆び始めると断ずるのは軽卒である。コンク

\section{図一1＼cjkstart軟鋼の腐蝕におよぼす $\mathrm{pH}$ の影響} (Uhlig, Corrosion Handbook, John Wiley \& Sons, 1938 の 129 ページに所載のもの)

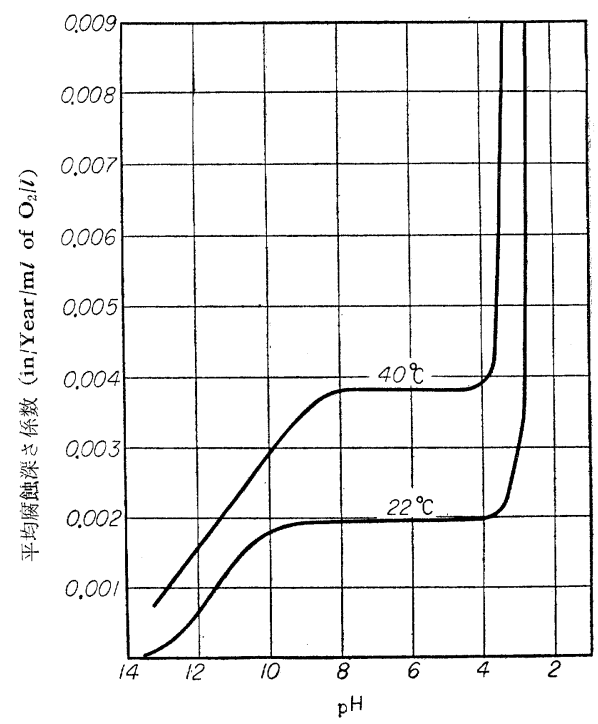
リートが中性化しても鉄筋が錆びるとは限らないのであって, 水と空気の接触が遮断に近い場合には鉄筋は錆びない。鉄筇の発錆はコンクリートの中性化よりもきわめて遅いと思わ和る。 Ryan の論文 ${ }^{1}$ Kよっても，pH 4 以下の酸性の場合には錆びは急激沉起こるが、ニンクリートが中性化したすなわち $\mathrm{pH}$ 7〜8の場合は,アルカリ性であった場合とほとえぞ同程度である(図一1 参照)。(ii) 鉄筋に対する影響としては, フライア ッシニの影響よりも，コンクリートの中性化によって生ずる炭酸石灰の影響の方を重視すべきであると信ずる。コンクリート 内に水と炭酸ガスとをらく空気が浸透すると次のような反応が起こる。

* 正員 工学博士 東京大学教授 工学部土木工学教室

** JIS A 6201-1958 


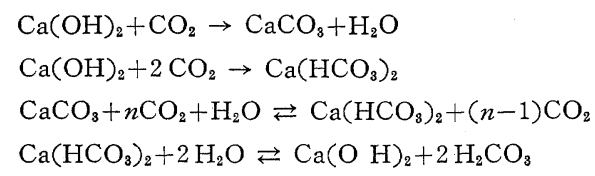

これによって鉄筋に錆び定生ずる2゙。すなわち,

$$
\begin{aligned}
& 2 \mathrm{Fe}+\mathrm{O}_{2} \rightarrow 2 \mathrm{FeO} \\
& 2 \mathrm{FeO}+2 \mathrm{H}_{2} \mathrm{CO}_{3} \rightarrow 2 \mathrm{FeCO}_{3}+\mathrm{H}_{2} \mathrm{O} \\
& 4 \mathrm{FeCO}_{3}+10 \mathrm{H}_{2} \mathrm{O}+\mathrm{O}_{2}=4 \mathrm{H}_{2} \mathrm{CO}_{3}+\frac{\mathrm{Fe}(\mathrm{OH})_{3}}{\frac{\text { 錆 }}{}}
\end{aligned}
$$

フライアッシニを用いると, (i) で述べたように珪酸石灰および䃕土酸石灰ができ, それだけ空気中の炭酸ガスによって造ら れる炭酸不灰は減少する。従って問題柱, 炭酸石灰と, 珪酸石灰および樊土酸石灰と, ぞちらが鉄を多く錆びさせるか, とい う問題になる。私の実験によっても，炭酸石灰はいちじるしく鉄安錆びさせるが珪酸石灰はそれほどいちじるしくないことが 確かめられている。”と反論された。

浜田委員は，(i）に対して実験結果 ${ }^{3), 43,5)}$ を挙げ，かぶりのコンクリートが中性化すれば，時間的に幾分のずれがあったと しても鉄笳は錆び始めると反論した。また，(ii）に対して，コンクリート中において炭酸石灰ができる $\mathrm{CaCO}_{3}+\mathrm{H}_{2} \mathrm{CO}_{3} \rightarrow$ $\mathrm{Ca}\left(\mathrm{HCO}_{3}\right)_{2}$ の反応速度はきわめて遅く, フライアッシュを用いても用いなくても生成される $\mathrm{Ca}\left(\mathrm{HCO}_{3}\right)_{2}$ の量には大差な いと思われる旨を述べた。両委員の討議はさらに続けられ，他の数名の委員からも各種の意見が開陳された。

“鉄笳の発錆は,フライアッシニの有無・鉄筋のかぶり・部材の露出状態などによって影響されるばかりでなく,これらの影響よ りもむしろ, コンクリートの配合・コンクリートの運搬打込み締固めの方法・養生などの影響の方がいちじるしいのであって 大念に設計施工されたコンクリートにおいては発錆について特別の考慮を必要としない”との論議もあり, 私もこれを強調し た一人であった。応力它受けつつある鉄筋の発錆はさらに複雑な問題であり,これらについての正しい結論を導くためには長期 にわたる試験が必要であるが,そのような試験の例が少なく, 大部分が促進中性化試験である現状では論議が紛紏するのも当然 であった。フライフッシニの使用が鉄筋の発錆におよ怙影響については，最後まで意見の一致がみられなかったのである。

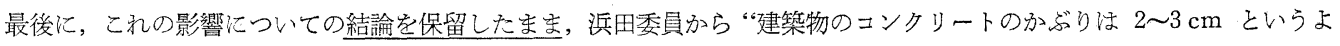
うに薄いので鉄筋が錆びる盧も大きい。も乙鉄笳が錆びると地震が起こった場合などに危険な事態が考えられる。このコンク リートにフライアッシュを不用意に用いるとさらに心配が増加することになるから，これに関する使用上の注意を付記して欲 しい”との要望が再三行なわれた。

それで吉田委員長は, “現状から推すと, 建築物のコンクリートは脱枠後はほとんど養生を行なわないし, 篇密にいえば脱 枠前にも完全な養生状態にあるとは認めがたい。従ってこれにフライアッシニを用いた場合, ポゾラン反忘が起こるかどうか はなはだ疑問である。またコンクリートの強度そのものも, 建築の場合注平均 $160 \mathrm{~kg} / \mathrm{cm}^{2}$ 程度であるし, 現在の施工状態で は建築のコンクリートにフライアッシュを入れたものは入れないものより劣る事は十分考えられる。浜田・張両委員の意見は 今後の実験研究によって解決することと思うので, 規格は 3 年ごとの見直しもあることであり, その時にはまた改めて考慮す ることにし，当面の問題として規格に付記をつけて使用者の注意を促すことが国家的にみてプラスならば付記をつけることに してはどうか?”と提案され，これに全委員が賛同したのでありました。

JIS の付記は以上のような次第で設けられたものでありまして, フライアッシュの使用と鉄筋の発錆との関係 は未解決のまま残されております。この関係について正しい結論を得るためには，促進試験だけでなく自然風化 による試験を行なうことがぜひ必要であります。三浦・杉木雨氏の御研究は鉄道トンネル内にモルタルを放置し た珍らしい実験ですが，御説のようにコンクリート中における鉄筋の発錆におよぼすフライアッシュの影響を暗 示するものと思い，與味深く拝聴しました。なお引続き御研究願います。また本日御参集の方々，特に若い研究 者の方々には，ての問題に強い関心をもっていただいて研究を推進して下さいますよう奶望致します。*

1) Ryan, J.P. : "Relationship of Fly Ash and Corrosion", J.A.C.I. Feb. 1951, p 481

2) 山本洋一：金属の腐蝕と防蝕, 共立社, 昭和 13 年

3）松下清夫・山田水域：鉄筋コンクリート構造建物の損傷について（雨仕舞に関する研究，その10）日本建築学会研究報 告第 27 号, 昭和 29 年 5 月

4）内田祥三・浜田 稔: 鋼およびコンクリートの耐久性試験, 建築杂倠誌, 昭和 3 年 12 月

5) 岸谷孝一: コンクリートの風化に関する研究

第 1 報 $\cdots$ 日本建築学会論文集 46 号, 昭和 28 年 3 月

第 2 報…” " " 47 号, 昭和 28 年 9 月

* 土木学会フライアッシニ小委員会では,今後の研究課題としてこの䦗題を採り上げ,実験に着手している(昭和 35 年 11 月) 


\section{討 議 者：左 右 田孝男*}

日本セメントK K 研究所においては，以前から高炉セメントその他を用いたコンクリートの中性化および鉄筋 の錆びについて研究を行なっており，先般材令 20 年における状態を試験し報告致しました1)。フライアッシュ を用いたコンクリート中の鉄筋の窝蝕についても，本年 3 月〜 4 月に 50 年分の供試体の製造を終って外気に曝 し, 研究を開始しております。三浦・杉木兩氏に、コンクリートでての種の試験を行なうとモルタル試験の場合 とどのように相違するか御意見を承りたいと存じます。

1）左右田孝男・山崎寬司：コンクリートの中性化と鉄筋のさびに関する 20 年試験, セメント シンクリート，昭和 33 年 (1958 年) 8 月

\section{答 弁:杉 木 共 郎**}

今回は促進試験を目的として，モルタル供試体でトンネル内放置といった特殊条件で行なったのであります。 しかし，モルタルとコンクリートとでは状態が異なるので，フライアッシュを混和したコンクリートの中性化と 鉄筋のさびの問題については, コンクリート供試体により長期試験をしなければならないと考えています。ての 問題について外国の $2 \sim 3$ の研究者に発した質問の答信にも，つぎのようにコンクリート供試体を用いるべきこ とを示唆しています。

1.イギリス国鉄技師長 Terris 氏よりは，「中性化の進行深さはコンクリートの空げきの多少に関倸することは間違いない ことで，小さなモルタル供試体で促進試験をすれば，中性化が進えでさびるということもあるであうう。しかし，小さな供試体 における中性化の状態は必ずしも大きなコンクリート部材の実際の状態を示すものとは考光られない。コンクリート部材では, 表面からせいぜい $1 / 2$-in 中性化しても，それ以上は容易に進行するもので洼ない」。またた，アメリカ道路局 Woolf 氏より は,「フライアッシニを混和したコンクリートについて実験したが，そのため中性化が余計に進行したといら結果はでなかった。 このコンクリートは，容積でセメントの $33 \%$ をフライアッシニでおきかえたもので亦る。コンクリート中の鉄筋のさびの防止 にはコンクリートが密実であることが一番大切で，フライアッシニの混和恬単位水量を減じることができるから，その点で岂し ろ有利と信じている」と。

2. アメリカ内務省開拓局 Price 氏よりは、「われわれの経験からは，フライアッシュコンクリートが鉄筋のさびに対しな えら心配すべきものと浪思われない。モルタル供試体による促進中性化試験では，フライアッシニ セメント ペーストのアル カリ性の消失は，ポルトランド セメント ペーストに怙ける場合より速いというととも考光られる。というのは, フライアッ シニがポゾラン作用で石灰の一部または全部と結合するからである。ペーストを粉砕し，乙れを短時間水沉浸した状態で試験す ると，ポゾランを混和したものが，アルカリ度注低くでるであるう。しかし，粉砕したペーストを長時間水に浸しておいて試験

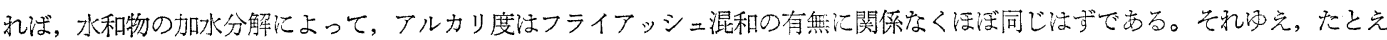
す過じよう水のある状態での促進試験でアルカリ度が低い值を示したとしても，現場のコンクリートでは，フライアッシニ ンクリートのアルカリ度はポルトランド セメント コンクリートのアルカリ度とほとえど同等であるとわれかれ和考光ている との答信がありました。

** 正員 日本セメント $\mathrm{KK}$

* 正員 小野田セメントKK 研究所 